\begin{tabular}{l|l} 
Rehabilitacja & \multicolumn{1}{c}{$\begin{array}{c}\text { DOI: 10.1515/rehab-2015-00 } \\
\text { Postępy Rehabilitacji (3), 27-39, }\end{array}$} \\
\hline \hline & $\begin{array}{l}\text { Ocena mobilności kompleksu kręgosłupowo - } \\
\text { miedniczno-biodrowego testem Trunk-Pelvis - Hip } \\
\text { Angle: rzetelność pomiarów jednego badacza oraz } \\
\text { różnice zakresów ruchu między dziewczętami ze } \\
\text { skoliozą idiopatyczną i zdrowymi }\end{array}$
\end{tabular}

A - opracowanie koncepcji i założeń (preparing concepts)

B - opracowanie metod (formulating methods)

C - przeprowadzenie badań (conducting research)

D - opracowanie wyników (processing results)

E - interpretacja i wnioski (nterpretation and conclusions)

$\mathrm{F}$ - redakcja ostatecznej wersji (editing the final version)

\section{Assessment of the lumbo-pelvic-hip complex mobility with the Trunk-Pelvis-Hip Angle test: intraobserver reliability and differences in ranges of motion between girls with idiopathic scoliosis and their healthy counterparts}

\author{
Agnieszka Stępień1 A-C,E, Katarzyna Guzek ${ }^{1 \text { B,C }}$, Witold Rekowski ${ }^{1}$,

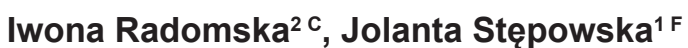
${ }^{1}$ Akademia Wychowania Fizycznego Józefa Piłsudskiego, Wydział Rehabilitacji, Warszawa
Jozef Pilsudski University of Physical Education, Faculty of Rehabilitation, Warsaw
${ }^{2}$ Centrum Rehabilitacji Funkcjonalnej ORTHOS, Warszawa
ORTHOS Functional Rehabilitation Centre, Warsaw

\title{
Streszczenie
}

Wstęp: Test Trunk-Pelvis - Hip Angle (TPHA) służy do oceny mobilności kompleksu kręgosłupowo - miedniczno - biodrowego. Celem badań była ocena rzetelności pomiarów wykonywanych w teście TPHA przez jednego badacza u dziewcząt ze skoliozą idiopatyczną i zdrowych oraz porównanie wartości TPHA uzyskanych przez dziewczęta w obu grupach.

Materiat $i$ metody: Badaniami objęto dziewczęta bez skoliozy oraz dziewczęta z dwułukową skoliozą idiopatyczną w wieku 8-16 lat. Pomiaru TPHA dokonywano trzykrotnie po każdej stronie ciała w czasie jednej sesji. Do analizy statystycznej wykorzystano współczynnik korelacji wewnątrz klasowej w wersji Anova dla grup zależnych, test Kołmogorowa-Smirnowa oraz testy nieparametryczne znaków rangowanych Wilcoxona dla grup zależnych i test Manna-Whitneya dla grup niezależnych.

Wyniki: W badaniu wzięło udział 49 zdrowych dziewcząt (wiek 11,8 \pm SD 2,5 lat) oraz

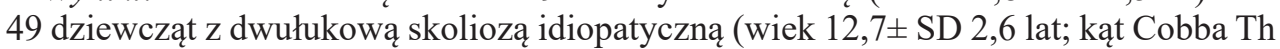
$27,70 \pm$ SD 13,40 i L Cobb 25,80 \pm SD 10,50). Poziom rzetelności powtarzanych pomiarów TPHA dla pojedynczego badacza wykazał bardzo wysoką zgodność (ICC $>0,85$ ). Wartość TPHA po lewej stronie była istotnie większa od wartości po prawej stronie ciała w obu grupach $(p=0,001)$. U dziewcząt ze skoliozą stwierdzono ograniczenie zakresu ruchu TPHA w prawo w porównaniu do dziewcząt bez skoliozy $(\mathrm{p}=0,001)$.

Wnioski: Test TPHA jest rzetelnym sposobem oceny ruchomości kompleksu kręgosłupowo-miedniczno-biodrowego u dziewcząt prowadzonej przez jednego badacza.

Asymetrię ruchów kompleksu kręgosłupowo-miedniczno-biodrowego występującą u zdrowych dziewcząt należy poddać obserwacji, ponieważ może stanowić jeden z czynników predysponujących do rozwoju skoliozy. Skolioza wpływa na ograniczenie zakresów ruchów rotacyjnych kręgosłupa. Test TPHA wymaga dalszych badań.

Słowa kluczowe: $\quad$ skolioza, rotacja, asymetria, rzetelność, TPHA 


\section{Abstract}

Introduction: The Trunk-Pelvis-Hip Angle (TPHA) test is used for assessing the mobility of lumbo-pelvic-hip complex. The aim of the research was to assess the intraobserver reliability of the TPHA test in girls with and without idiopathic scoliosis and to compare the test values obtained by the girls in both groups.

Material and methods: The research included girls without scoliosis and girls with double idiopathic scoliosis aged 8-16. The trunk-pelvis-hip angle was measured three times on each body side within one session. Statistical analysis was performed with the use of ANOVA intraclass correlation coefficient for dependent groups, KolmogorovSmirnov test as well as non-parametric Wilcoxon signed-rank test for dependent groups and Mann-Whitney $\mathrm{U}$ test for independent groups.

Results: The research included 49 healthy girls (aged $11.8 \pm$ SD 2.5 years) and 49 girls with double idiopathic scoliosis (aged 12.7 \pm SD 2.6 years; Cobb angle Th $27.7^{\circ} \pm$ $\mathrm{SD} 13.4^{\circ}$ and $\mathrm{L}$ Cobb $25.8^{\circ} \pm \mathrm{SD} 10.5^{\circ}$ ). The intraobserver reliability for the TPHA measurements was very high (ICC $>0.85$ ). In both groups the left-side TPHA value was significantly higher than the right-side value $(\mathrm{p}=0.001)$. The TPHA range of motion on the right side of the body was more limited in the scoliotic girls than in the healthy ones $(\mathrm{p}=0.001)$.

Conclusions: The TPHA test is a reliable means of assessing mobility in the lumbopelvic-hip complex in girls by one observer.The asymmetry of movements in the lumbo-pelvic-hip complex in healthy girls needs to be observed since it may constitute one of the factors predisposing to scoliosis which limits spine rotation range of motion. The TPHA test needs further research.

Key words: $\quad$ scoliosis, rotation, asymmetry, reliability, TPHA

\section{Wstęp}

Ciało ludzkie funkcjonuje jako całość dzięki współpracy wielu systemów. Zaburzenia funkcji ruchowej jednego z podsystemów mogą wpływać na działanie pozostałych i wywoływać negatywne kompensacje w narządzie ruchu. $Z$ tego właśnie względu ważna jest wnikliwa ocena jego poszczególnych części.

Wielu autorów dostrzega znaczenie kompleksu kręgosłupowo - miedniczno - biodrowego w codziennym funkcjonowaniu ciała ludzkiego. Ruchy tej części ciała ludzkiego, w tym ruchy rotacyjne, są składową większości ruchów związanych z przemieszczaniem ciała w przestrzeni w pozycji leżącej, siedzącej, w chodzie [1,2] oraz podczas biegu [3]. Zaburzenia mobilności kompleksu kręgosłupowo- miednicznobiodrowego zaobserwowano między innymi u osób z zespołem bólowym odcinka lędźwiowego kręgosłupa i innymi dysfunkcjami narządu ruchu $[4,5,6,7,8$, 9], chorobą Parkinsona [10] oraz u młodzieży ze skoliozą [11].

Pomiary zakresów ruchu są istotną składową diagnostyki funkcjonalnej osób z różnymi dysfunkcjami i chorobami. Wykonuje się je w celu określenia szczegółowych celów fizjoterapii oraz opisania efektów podejmowanych działań leczniczych. Wczesne wykrycie zaburzeń funkcji ruchowej w narządzie ruchu umożliwia wdrożenie działań profilaktycznych i zapobie-

\section{Introduction}

A human body functions as a whole owing to the cooperation of many systems. The mobility dysfunction of one of the sub-systems may affect the functioning of the other ones and bring about negative compensations in the musculoskeletal system. Therefore, it is significant to perform a detailed analysis of its particular elements.

Numerous authors recognise the significance of lumbar-pelvic-hip complex in an everyday functioning of a human body. Movements in this part of the body, including rotational movements, belong to the group of movements connected with moving the body in a supine, sitting and walking position $[1,2]$ as well as while running [3]. The disorders of the mobility of lumbar-pelvic-hip complex were noted, inter alia, in individuals with pain syndrome of the lumbar spine, other musculoskeletal system disorders $[4,5,6,7,8$, 9] and Parkinson's disease [10] as well as in scoliotic youth [11].

The measurements of the ranges of motion are a significant element of the functional diagnostics of individuals with various dysfunctions and diseases. They are performed in order to define detailed objectives of physiotherapy and to describe effects of the undertaken treatment. An early diagnosis of the mobility dysfunctions in the musculoskeletal disorders 
ganie nieprawidłowym mechanizmom kompensacyjnym.

Kilku badaczy podjęło próbę oceny metod pomiarów zakresów ruchu kręgosłupa i miednicy wykorzystując nowoczesne systemy pomiarowe, które nie znajdują zastosowania

W codziennej praktyce klinicznej [5, 12, 13, 14]. Inni autorzy analizowali i weryfikowali różne proste metody oceny ruchomości kręgosłupa $[15,16,17$, 18, 19, 20, 21]. Dotychczas opisano niewiele testów umożliwiających ocenę zakresu ruchu kręgosłupa i miednicy w płaszczyźnie poprzecznej [22, 23].

Test Trunk -Pelvis- Hip Angle (TPHA) prezentowany w niniejszej pracy został opracowany na podstawie wieloletnich obserwacji wzorców ruchowych i biomechaniki narządu ruchu osób ze skoliozą idiopatyczną oraz wyników badań prowadzonych w przeszłości przez autorów. W badaniach tych wykazano występowanie różnic $\mathrm{w}$ zakresach ruchów rotacyjnych tułowia i miednicy po lewej i prawej stronie ciała u dziewcząt ze skoliozą idiopatyczną oraz ograniczenia zakresów tych ruchów w stosunku do dziewcząt bez skoliozy [11]. Test TPHA może być wykorzystywany do pomiaru zakresu złożonego ruchu kompleksu kręgosłupowo - miedniczno - biodrowego u dzieci i młodzieży z wadami postawy lub skoliozą.

Celem przeprowadzonych badań była ocena rzetelności pomiarów wykonywanych w teście TPHA przez jednego badacza (ang. intraobserver raliability) u dziewcząt ze skoliozą idiopatyczną i zdrowych. Dodatkowym celem było porównanie zakresów ruchu uzyskanych przez dziewczęta w obu grupach.

\section{Materiał i metody}

Badaniami objęto dziewczęta bez skoliozy oraz dziewczęta ze skoliozą idiopatyczną, które kwalifikowano odpowiednio do dwóch grup: H- grupy dziewcząt zdrowych, S oraz grupy dziewcząt ze skoliozą.

Do grupy H włączano uczennice szkoły podstawowej i gimnazjum, które zgłosiły się na badania przesiewowe postawy ciała, zorganizowane w szkole na prośbę dyrektora. Za warunki włączenia do grupy $\mathrm{H}$ uznano: wiek 8-16 lat, brak skoliozy idiopatycznej lub innej, kąt rotacji tułowia poniżej 50, brak dolegliwości bólowych, brak urazów w okresie 12 miesięcy przed badaniem, brak chorób układu kostnego, mięśniowego, nerwowego i chorób układowych, zgoda rodziców lub opiekunów prawnych na udział w badaniu.

Do grupy S kwalifikowano dziewczęta ze skoliozą idiopatyczną zgłaszające się kolejno do ośrodka wyspecjalizowanego w fizjoterapii dzieci i młodzieży z wadami postawy. Warunkiem włączenia do grupy S były: wiek 8-16 lat, płeć żeńska, występowanie dwułukowej skoliozy idiopatycznej z łukiem prawostronnym piersiowym i łukiem lewostronnym lędźwio- makes it possible to implement prophylactic activities and to prevent improper compensation mechanisms.

Some researchers tried to assess the method of measuring the range of motion in the spine and pelvis with the use of modern measurement systems which are not applied in an everyday clinical practice $[5,12$, $13,14]$. Other authors analysed and verified various simple methods of assessing spinal mobility $[15,16$, $17,18,19,20,21]$. To date, not many tests assessing the range of motion in the transverse plane of the spine and pelvis have been described [22, 23].

The Trunk-Pelvis-Hip Angle (TPHA) test presented in this work was developed on the basis of long-term observations of movement patterns and biomechanics of the musculoskeletal system in scoliotic individuals as well as our previous research results. The research revealed differences in rotational ranges of motion of the spine and pelvis between the left and right side of the body in girls with idiopathic scoliosis and bigger limitations of these ranges of motion compared to girls without scoliosis [11]. The TPHA test may be used for measuring the range of motion of lumbar-pelvic-hip complex in children and youth with posture faults and scoliosis.

The aim of the research was to assess the intraobserver reliability of the TPHA test in girls with and without idiopathic scoliosis. Additionally, the study was aimed at comparing the test values obtained by the girls in both groups.

\section{Material and methods}

The research included healthy girls and girls with idiopathic scoliosis who were assigned to two groups: $\mathrm{H}$ - healthy girls, $\mathrm{S}$ - girls with scoliosis.

Group $\mathrm{H}$ included pupils from the primary and lower-secondary school who participated in body posture screening organised at the school director's request. Group $\mathrm{H}$ inclusion criteria included age (8-16 years), the lack of idiopathic or any other type of scoliosis, trunk rotation angle below $5^{\circ}$, the lack of pain, no injuries for 12 months prior to the study, no diseases of the osseous, muscular or nervous system, no systemic diseases, a consent given by parents or legal guardians.

Group S included girls with idiopathic scoliosis who subsequently visited the centre specialising in physiotherapy of children and youth with faulty body postures. Group S inclusion criteria included age (816 years), gender (female), double idiopathic scoliosis with right-side thoracic curve and left-side lumbar curve diagnosed on the basis of radiography, each curve size minimum $10^{\circ}$ according to Cobb, no pain, no injuries for 12 months prior to the study, no other diseases of the osseous, muscular or nervous system, no systemic diseases, a consent given by parents or legal guardians. 
wym, rozpoznanym na podstawie zdjęcia rentgenowskiego, wielkość każdego łuku minimum 100 wg Cobba, brak dolegliwości bólowych, brak urazów w okresie 12 miesięcy przed badaniem, brak innych chorób układu kostnego, mięśniowego, nerwowego i chorób układowych, zgoda rodziców lub opiekunów prawnych na udział w badaniu.

Badanie jest częścią projektu ocenionego pozytywnie przez Senacką Komisję Etyki Badań Naukowych w Akademii Wychowania Fizycznego Józefa Piłsudskiego w Warszawie.

U wszystkich badanych w obu grupach dokonano oceny postawy ciała według wcześniej ustalonego protokołu. Test TPHA stanowił jeden z punktów badania. Badanie było przeprowadzane przez fizjoterapeutę z długim stażem pracy i dużym doświadczeniem w pracy z młodzieżą ze skoliozą. Pomiaru TPHA dokonywano w pozycji leżącej na plecach na stole terapeutycznym $\mathrm{z}$ regulowaną wysokością. Kończyny górne osoby badanej ustawiane były prostopadle do tułowia, ze zgiętymi łokciami, kończyny dolne były wyprostowane. Osoba badana proszona była o zgięcie kończyn dolnych w kierunku klatki piersiowej, do chwili oderwania kości krzyżowej, a następnie wykonanie ruchu kończynami dolnymi w kierunku lewego łokcia (TPHAleft). Badacz dokonujący pomiaru ustawiony był po prawej stronie osoby badanej. Przedramię lewej kończyny górnej badacza ułożone było prostopadle do osi długiej tułowia osoby badanej na wysokości łuków żebrowych. Prawa kończyna górna pomagała w zgięciu kończyn dolnych osoby badanej, a następnie, po przeniesieniu obu kończyn dolnych w kierunku lewego łokcia, dokonywała pomiaru Plurimetrem Rippsteina. Plurimetr zerowano względem podłoża i przykładano wzdłuż osi długiej uda przy szparze stawu kolanowego (Rycina 1a). W przypadku ustawienia osi długiej uda poniżej poziomu wartości zapisywano ze znakiem ”-,,, zaś powyżej poziomu ze znakiem ,,+”. Ruch kończyn dolnych osoby badanej w kierunku łokcia wykonywany był powoli, do chwili wyczucia wstępnego ruchu żeber pod przedramieniem badacza. Warunkiem prawidłowo wykonanego pomiaru było utrzymanie żeber osoby badanej na podłożu. Pomiaru dokonywano po pięciu sekundach po osiągnięciu końcowego zakresu ruchu. Po dokonaniu pomiaru badacz przechodził na drugą stronę stołu i wykonywał pomiar TPHA po prawej stronie ciała (TPHAright) (Rycina 1b).

W obu grupach dokonano trzykrotnego pomiaru, naprzemiennie po lewej i prawej stronie ciała, zaczynając od ruchu w lewo. Uczestniczki badań ubrane były w strój sportowy, nie krepujący ruchów. Pomiary we wszystkich grupach wykonywane były tego samego dnia,

w czasie jednej sesji, w odstępach 3 minutowych. Po wykonaniu pomiaru zakresu ruchu po lewej i po
The research was part of the project approved by the Senate Research Ethics Committee at Jozef Pilsudski University of Physical Education in Warsaw.

Body posture of all the girls in both groups was assessed according to a previously prepared protocol. The TPHA test was one of the elements of the assessment. The examination was performed by a physiotherapist with long experience of working with scoliotic youth. The TPHA measurement was made on a subject in a supine position on a therapeutic table with a changeable height. Upper limbs were held perpendicularly to the trunk with elbows flexed while lower limbs were held straight. The subject was asked to flex lower limbs and pull them towards the chest until the sacral bone was lifted up and then to move the limbs towards the left elbow (TPHAleft). The researcher making an assessment was standing on the right side of the subject. The forearm of the left upper limb of the researcher was placed perpendicularly towards the long axis of the trunk of the subject close to the coastal arch. The right upper limb was used to help the subject flex lower limbs and then, after moving both lower limbs towards the left elbow, it was used to perform the measurement with Rippstein Plurimeter. The Plurimeter was reset to zero in relation to the surface and placed along the long thigh axis close to the gap at the knee joint (Figure 1a). If the long thigh axis was below the level, the values were marked with "-“", while if it was above the level, they were marked with "+". The movement of the lower limbs towards the elbow was performed slowly until the initial rib movement was felt by the physiotherapist. Keeping the subject's ribs on the surface was the condition for performing the measurement properly. The measurement was made five seconds after reaching the final range of motion. After the measurement the physiotherapist moved to the other side of the table and performed the TPHA test on the right side of the body (TPHAright) (Figure 1b).

In both groups the measurement was performed three times, alternately on the left and right side of the body, beginning from the movement to the left. The subjects were wearing sports clothes that did not impede their movements. In all the groups the measurements were made on the same day, during one session with 3-minute intervals. After the measurement of the range of motion on the left and right side of the body, the subject stood up and after a while the examination was resumed.

In order to define the intraobserver reliability in both groups the ANOVA intraclass correlation coefficient (ICC) for dependent groups was applied using absolute concordance definition. When assessing the reliability, it was established that the value of the coefficient lower than 0.40 meant low reliability, between 0.40 and 0.59 - acceptable, between 0.60 and 0.74 - good, between 0.75 and 1.00 - excellent [24]. 

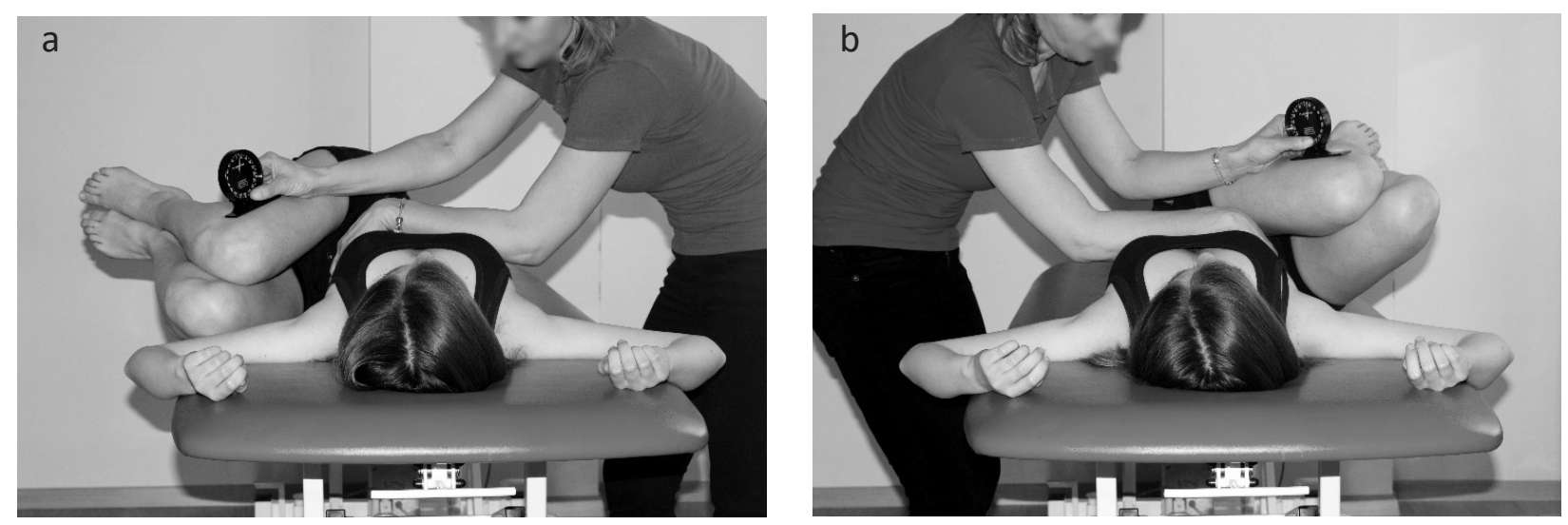

Ryc. 1a. Pomiar wartości TPHA po lewej stronie ciała badanej osoby

Fig. 1a. The measurement of TPHA values on the left side of the subject's body

Ryc. 1b. Pomiar wartości TPHA po prawej stronie ciała badanej osoby

Fig. 1b. The measurement of TPHA values on the right side of the subject's body

prawej stronie ciała osoba poddana badaniu wstawała, a po chwili ponawiano pomiar.

W celu określenia poziomu rzetelności pomiarów dokonywanych przez pojedynczego badacza, w obu grupach zastosowano współczynnik korelacji wewnątrzklasowej (ang. interclass correlation coeficient - ICC) w wersji Anova dla grup zależnych z wykorzystaniem definicji bezwzględnej zgodności. Przy ocenie rzetelności przyjęto kryterium: wartość współczynnika mniej niż 0.40 - niewielka, pomiędzy 0.40 i 0.59 - akceptowalna, pomiędzy 0.60 i 0.74 - dobra, pomiędzy 0.75 i 1.00 - znakomita [24]. Do porównań średnich w obu grupach i pomiędzy grupami posłużono się średnimi wyliczonymi z trzech pomiarów TPHA dokonywanych po lewej i prawej stronie ciała. Podano również wartości odchylenia standardowego oraz błędu standardowego średnich. Dokonując porównania średnich pomiarów testem TPHA normalność rozkładów w badanych grupach oceniono przy pomocy testu Kołmogorowa - Smirnowa. Ze względu na brak normalności rozkładów w grupie zdrowych dziewcząt (H) w pomiarze rotacji w lewo i w grupie dziewcząt ze skoliozą (S) w pomiarze rotacji w lewo i w prawo, do porównań średnich zastosowano testy nieparametryczne: znaków rangowanych Wilcoxona dla grup zależnych i test Manna-Whitneya dla grup niezależnych. We wszystkich analizach przyjęto poziom istotności $\mathrm{p}$ $=0,05$. Obliczenia statystyczne wykonano wykorzystując pakiet statystyczny IBM SPSS Statistics wersja 20.

\section{Wyniki}

W badaniu wzięło udział 49 zdrowych dziewcząt (wiek 11.8 lat \pm SD 2.5; wysokość ciała $150.9 \mathrm{~cm} \pm$ SD 13.3; masa ciała $42.8 \mathrm{~kg} \pm$ SD 12.3) oraz 49 dziewcząt z dwułukową skoliozą idiopatyczną (wiek 12.7 lat
In order to compare the means within both groups and between them, the mean values calculated from three TPHA measurements made on the left and right side of the body were used. Additionally, values of standard deviation and standard error of measurement for these means were provided. When comparing the means of TPHA measurements, the normal distribution in the examined groups was assessed with the use of Kolmogorov-Smirnov test. Due to the lack of normal distribution values in the group of healthy girls (H) for the measurement of the rotation to the left and in the group of scoliotic girls (S) for the measurements of the rotation to the left and right, the means were compared with the use of non-parametric tests, i.e. Wilcoxon signed-rank test for dependent groups and Mann-Whitney U test for independent groups. For all the analyses, the significance level was set at $p=0.05$. Statistical calculations were made with the use of IBM SPSS Statistics (version 20) software.

\section{Results}

The research included 49 healthy girls (age -11.8 years \pm SD 2.5; body height $-150.9 \mathrm{~cm} \pm \mathrm{SD} 13.3$; body mass $-42.8 \mathrm{~kg} \pm \mathrm{SD} 12.3$ ) and 49 girls with double idiopathic scoliosis (age -12.7 years \pm SD 2.6; body height $-156.0 \mathrm{~cm} \pm \mathrm{SD} 14.1$; body mass -45.4 $\mathrm{kg} \pm \mathrm{SD} 11.3$ ).

The mean value of the curve according to Cobb in the group of scoliotic girls was $27.7^{\circ}$ ( \pm SD 13.4) in the thoracic segment and $25.8^{\circ}( \pm \mathrm{SD} 10.5)$ in the lumbar spine. Twenty-seven scoliotic girls were undergoing corset treatment. In the Risser sign, 14 girls with scoliosis were given grade 0,11 girls - grade 1 , 6 girls - grade 2, 3 girls - grade 3, 9 girls - grade 4 and six girls - grade 5. On the basis of the international guidelines concerning the types of scoliosis 
Tab. 1. Średnie wartości testu Trunk-Pelvis-Hip Angle (TPHA) po lewej (TPHAleft) i prawej (TPHAright) stronie ciała, wartości standardowego błędu pomiaru (SEM) i odchylenia standardowego (SD) w grupie dziewcząt zdrowych (H) i ze skoliozą (S) Tab. 1. Average values of Trunk-Pelvis-Hip Angle test (TPHA) on the left (TPHAleft) and right (TPHAright) side of the body, values of standard error of measurement (SEM) and standard deviation (SD) in the group of healthy $(\mathrm{H})$ and scoliotic (S) girls

\begin{tabular}{|l|c|c|c|c|c|c|}
\hline & $\begin{array}{c}\text { TPHAleft } \\
\text { (w stopniach) } \\
\text { TPHAleft } \\
\text { (in degrees) }\end{array}$ & $\begin{array}{c}\text { SEM / } \\
\text { TPHAleft }\end{array}$ & $\begin{array}{c}\text { SD/ } \\
\text { TPHAleft }\end{array}$ & $\begin{array}{c}\text { TPHAright } \\
\text { ( w stop- } \\
\text { niach) } \\
\text { TPHAright } \\
\text { in degrees) }\end{array}$ & $\begin{array}{c}\text { SEM/ } \\
\text { TPHAright }\end{array}$ & $\begin{array}{c}\text { SD/ } \\
\text { TPHAright }\end{array}$ \\
\hline $\begin{array}{l}\text { Dziewczęta zdrowe (H) } \\
\text { Healthy girls (H) }\end{array}$ & $-11,00$ & 0,47 & 3,30 & $-8,64$ & 0,67 & 4,70 \\
\hline $\begin{array}{l}\text { Dziewczęta ze skoliozą (S) } \\
\text { Scoliotic girls (S) }\end{array}$ & $-10,93$ & 0,66 & 4,64 & $-2,37$ & 1,19 & 8,30 \\
\hline
\end{tabular}

\pm SD 2.6; wysokość ciała $156.0 \mathrm{~cm} \pm \mathrm{SD} 14.1$; masa ciała $45.4 \mathrm{~kg} \pm \mathrm{SD} 11.3)$.

Średnia wartość skrzywienia według Cobba w grupie dziewcząt ze skoliozą wynosiła 27.70 ( \pm SD 13.4) w odcinku piersiowym oraz $25.80( \pm$ SD 10.5) w odcinku lędźwiowym. 27 badanych dziewcząt ze skoliozą było w trakcie leczenia gorsetowego. Test Rissera został oceniony na: $0 \mathrm{u}$ czternastu, $1 \mathrm{u}$ jedenastu, 2 u sześciu, 3 u trzech, 4 u dziewięciu i 5 u sześciu dziewcząt ze skoliozą. Na podstawie podziału skolioz przyjętego w wytycznych międzynarodowych [25] u 7 dziewcząt rozpoznano niskostopniową skoliozę (do 150 wg Cobba), u 9 stwierdzono skoliozę niskostopniową do średniej (16-240), u 15 dziewcząt średnią skoliozę (25-340), u 14 dziewcząt skoliozę średnią do dużej (35-440) i u 4 dużą skoliozę (45-590). 28 dziewcząt z grupy $\mathrm{S}$ korzystało wcześniej z różnych form fizjoterapii.

Średnie wartości zakresów ruchu TPHA, wartości standardowego błędu i odchylenia standardowego, uzyskane przez uczestniczki badań podczas wykonywania testu TPHA, umieszczono w Tabeli 1.

Poziom rzetelności ICC powtarzanych pomiarów TPHA po lewej i prawej stronie ciała dla pojedynczego badacza zarówno w grupie dziewcząt bez skoliozy jak i w grupie dziewcząt ze skoliozą wyniósł ponad 0,85 , wykazując bardzo wysoką zgodność. Szczegółowe dane odnośnie poziomu współczynnika korelacji wewnątrzklasowej dla jednego badacza oraz 95\% przedziału ufności umieszczono w Tabeli 2.

Przeprowadzone badania poza wiedzą na temat wiarygodności pomiarów dokonywanych w teście TPHA wniosły kilka dodatkowych istotnych informacji odnośnie mobilności kompleksu kręgosłupowo - miedniczno- biodrowego u dziewcząt bez skoliozy i ze skoliozą. Porównanie średnich wartości TPHA pozwoliło na zbadanie różnic między zakresami ruchu po lewej i prawej stronie ciała w obu badanych grupach.

Zaobserwowano, że w obu badanych grupach dziewczęta wykonują ruch w lewo (TPHAleft) w istotnie większym zakresie niż w prawo TPHAright (Tabela 3).
[25], 7 girls were diagnosed with low scoliosis (up to $15^{\circ}$ according to Cobb), 9 girls - with low to moderate scoliosis $\left(16-24^{\circ}\right), 15$ girls - with moderate scoliosis $\left(25-34^{\circ}\right), 14$ girls - with moderate to severe scoliosis $\left(35-44^{\circ}\right)$ and 4 girls - with severe scoliosis $\left(45-59^{\circ}\right)$. Twenty-eight girls from group $\mathrm{S}$ had previously undergone different forms of physiotherapy.

Mean values of TPHA range of motion, standard error of measurement and standard deviation obtained by the girls during TPHA test are included in Table 1 .

The intraobserver reliability of ICC of the repeated TPHA measurements on the left and right side of the body in both groups was higher than 0.85 , which indicated very high reliability. Detailed data concerning the level of the intraclass correlation coefficient for intraobserver reliability and $95 \%$ confidence intervals are included in Table 2.

Apart from the data on the TPHA measurements reliability, our research provided additional significant information regarding the mobility of trunk-pelvis-hip complex in healthy girls and girls with scoliosis. The comparison of the mean values of TPHA enabled us to examine the differences between the ranges of motion on the left and right side in both groups. It was noted that in both groups of girls the movement to the left (TPHAleft) had a significantly higher range of motion than the movement to the right (TPHAright) (Table 3).

In the group of healthy girls, the values of the TPHAleft range of motion were higher in 34 out of 49 girls $(70 \%)$; however, only in 15 of them $(30 \%)$ the values obtained on the left side were higher than the values on the right side by 4 degrees or more. In turn, in scoliotic girls, higher TPHAleft ranges of motion were noted in 42 out of 49 girls $(85 \%)$, while in 33 girls $(68 \%)$ the difference between TPHAleft and TPHAright was higher by 4 degrees or more.

The comparison of the TPHA values obtained by the healthy girls in group $\mathrm{H}$ and the values obtained by the girls in group $\mathrm{S}$ revealed that scoliotic girls performed the TPHA movement on the right side of the body with a significantly smaller range of motion than healthy girls. Simultaneously, no significant dif- 
Tab. 2. Rzetelność pomiarów jednego badacza w czasie jednej sesji - współczynnik korelacji wewnątrzklasowej (ICC) oraz 95\% przedział ufności w powtarzanych pomiarach testem Trunk-Pelvis-Hip Angle (TPHA) po lewej (TPHAleft) i prawej (TPHAright) stronie ciała w grupie dziewcząt zdrowych $(\mathrm{H})$ i ze skoliozą $(\mathrm{S})$.

Tab. 2. Intraobserver reliability within one session - intraclass correlation coefficient (ICC) and 95\% confidence intervals in the repeated measurements of Trunk-Pelvis-Hip Angle (TPHA) test on the left (TPHAleft) and right (TPHA right) side of the body in the group of healthy $(\mathrm{H})$ and scoliotic $(\mathrm{S})$ girls.

\begin{tabular}{|l|c|c|c|c|c|c|}
\hline & \multicolumn{3}{|c|}{ TPHA left } & & \multicolumn{3}{c|}{ THPA right } \\
\cline { 2 - 7 } & $\begin{array}{c}\text { ICC dla jednego } \\
\text { badacza } \\
\text { ICC for a single } \\
\text { researcher }\end{array}$ & $\begin{array}{c}95 \% \text { przedział } \\
\text { ufności } \\
95 \text { confidence } \\
\text { interval }\end{array}$ & $\mathrm{p}$ & $\begin{array}{c}\text { ICC dla jednego } \\
\text { badacza } \\
\text { ICC for a single } \\
\text { researcher }\end{array}$ & $\begin{array}{c}95 \% \text { przedział } \\
\text { ufności } \\
95 \% \text { confidence } \\
\text { interval }\end{array}$ & $\mathrm{p}$ \\
\hline $\begin{array}{l}\text { Dziewczęta } \\
\text { zdrowe (H) } \\
\text { Healthy girls (H) }\end{array}$ & 0.872 & $0.805-0.920$ & 0.001 & 0.810 & $0.718-0.880$ & 0.001 \\
\hline $\begin{array}{l}\text { Dziewczęta ze } \\
\text { skoliozą (S) } \\
\text { Scoliotic girls (S) }\end{array}$ & 0.942 & $0.901-0.966$ & 0.001 & 0.976 & $0.956-0.987$ & 0.001 \\
\hline
\end{tabular}

Tab. 3. Porównanie średnich wartości testu Trunk-Pelvis-Hip Angle (TPHA) po lewej (TPHAleft) i prawej (TPHAright) stronie ciała wewnątrz grup i między grupami dziewcząt zdrowych (H) i ze skoliozą (S).

Tab. 3. Comparison of average values of Trunk-Pelvis-Hip Angle test (TPHA) on the left (THPAleft) and right (TPHAright) side of the body within and between the groups of healthy $(\mathrm{H})$ and scoliotic $(\mathrm{S})$ girls.

\begin{tabular}{|l|l|l|}
\hline $\begin{array}{l}\text { TPHA / Grupa } \\
\text { TPHA / Group }\end{array}$ & $\begin{array}{l}\text { Porównanie średnich wartości TPHA wewnątrz grup i między } \\
\text { grupami Comparison of average values of TPHA within and be- } \\
\text { tween the groups }\end{array}$ & $\mathrm{p}$ \\
\hline $\begin{array}{l}\text { TPHAleft i TPHAright w grupie dziewcząt } \\
\text { zdrowych (H) } \\
\text { TPHAleft and TPHAright in the group of } \\
\text { healthy girls (H) }\end{array}$ & TPHAleft H (-11.000) vs TPHAright H (-8.640) & $\mathrm{p}=0.001$ \\
\hline $\begin{array}{l}\text { TPHAleft i TPHAright w grupie dziewcząt } \\
\text { ze skoliozą (S) } \\
\text { TPHAleft and TPHAright in the group of } \\
\text { scoliotic (S) girls }\end{array}$ & TPHAleft S (-10.930) vs TPHAright S (-2.370) & $\mathrm{p}=0.001$ \\
\hline $\begin{array}{l}\text { TPHAleft w grupach dziewcząt zdrowych } \\
\text { (H) i ze skoliozą (S) } \\
\text { TPHAleft in the groups of healthy (H) and } \\
\text { scoliotic (S) girls }\end{array}$ & TPHAleft H (-11.000) vs TPHAleft S (-10.92) & $\mathrm{p}=0.963$ \\
\hline $\begin{array}{l}\text { TPHAright w grupach dziewcząt zdrowych } \\
\text { (H) i ze skoliozą (S) } \\
\text { TPHAright in the groups of healthy (H) and } \\
\text { scoliotic (S) girls }\end{array}$ & TPHAright H (-8.640) vs TPHAright S $(-2.37)$ & $\mathrm{p}=0.001$ \\
\hline
\end{tabular}

W grupie dziewcząt bez skoliozy wartości zakresu TPHAleft były większe u 34 z 49 dziewcząt (70\%), ale tylko u $15 \mathrm{z}$ nich (30\%) wartości uzyskane po stronie lewej były większe od wartości po prawej stronie o 4 stopnie i więcej. Z kolei u dziewcząt ze skoliozą większe zakresy ruchu TPHAleft zaobserwowano u 42 na 49 zbadanych dziewcząt ( $85 \%$ ), a u 33 uczestniczek (68\%) różnica między TPHAleft i TPHAright była większa o 4 stopnie i więcej.

Odniesienie wartości TPHA uzyskanych przez zdrowe dziewczęta $\mathrm{w}$ grupie $\mathrm{H}$ do wartości w grupie S wykazało, że dziewczęta ze skoliozą wykonują ruch TPHA po prawej stronie ciała w znacznie mniejszym zakresie niż dziewczęta bez skoliozy. Równocześnie nie stwierdzono znamiennych różnic między wartościami TPHAleft w obu grupach (Tabela 3). ferences were noted between the TPHAleft values in both groups (Table 3 ).

\section{Discussion}

The aim of the research was to assess the intraobserver reliability of the TPHA test. Both in the group of healthy girls and in the group of girls with scoliosis the intraclass correlation coefficient (ICC) values were above 0.8 , which proves a high level of the compatibility of the measurements and the reliability of the test [24]. The obtained results showed that TPHA test is reliable and may be applied in the everyday functional diagnostics of children and youth.

The result of the measurement, or actually, the error of measurement may result from the error of the device used, inconsistency with the test protocol or the quality of the test performance [26]. In this research, the 


\section{Dyskusja}

Celem prezentowanych badań była ocena rzetelności pomiarów w teście TPHA wykonywanych przez jednego badacza. Zarówno w grupie dziewcząt bez skoliozy jak i w grupie dziewcząt ze skoliozą uzyskano wartości współczynnika korelacji wewnątrzklasowej (ICC) powyżej 0,8 , co odpowiada wysokiemu poziomowi zgodności pomiarów i rzetelności stosowanego testu [24]. Uzyskane wyniki wskazują, że TPHA można uznać za wiarygodny test, który może być stosowany w diagnostyce funkcjonalnej dzieci i młodzieży w codziennej praktyce.

Wynik pomiaru, a w zasadzie błąd pomiaru, może wynikać z błędu związanego ze stosowanym urządzeniem, niezgodności z protokołem badania oraz jakości wykonania testu przez badaczy [26]. W niniejszych badaniach badacz używał tego samego urządzenia - plurimetru Rippsteina, oceniając tą samą osobę w krótkich odstępach czasu. Plurimetr Rippsteina był dotychczas wykorzystywany w badaniach naukowych do pomiarów kątowych ustawienia i ruchów kręgosłupa, stawu barkowego i stawu biodrowego [12, 27, 28, 29, 30]. Teoretycznie na wartość pomiaru największy wpływ mogła mieć budowa ciała badanych dziewcząt i jakość realizacji zaplanowanego protokołu.

Przed rozpoczęciem badań, $\mathrm{w}$ trakcie doskonalenia wykonywania testu TPHA przez badacza, największym problemem było zdobycie umiejętności wyczuwania końcowego zakresu ruchu, równoczesna stabilizacja klatki piersiowej osoby badanej i dokonywanie pomiaru plurimetrem. Dlatego w trakcie przeprowadzonych badań każdorazowo test wykonywano powoli, ze szczególnym uwzględnieniem stabilizacji klatki piersiowej, a pomiaru dokonywano po pięciu sekundach od zakończenia ruchu. Zwiększonej kontroli ze strony badacza wymagało przeprowadzenie testu u osób z większą masą ciała. $Z$ tego względu należy przeprowadzić ocenę rzetelności pomiarów testem TPHA u osób dorosłych.

Trudno odnieść wyniki prezentowanych badań do rezultatów uzyskanych przez innych badaczy, bowiem według wiedzy autorów nikt dotychczas nie wprowadzał i nie zweryfikował takiej metody oceny zakresu ruchu kompleksu kręgosłupowo- miedniczno-biodrowego.

W przeprowadzonych badaniach, w obu badanych grupach, stwierdzono istotne różnice miedzy zakresami ruchu TPHA po lewej i prawej stronie ciała. U większości badanych dziewcząt zakres ruchu TPHAleft był większy od zakresu TPHAright.

Nierówne zakresy ruchu u dziewcząt bez skoliozy mogą mieć związek z fizjologicznym asymetrycznym ustawieniem kręgów w płaszczyźnie poprzecznej zaobserwowanych u dzieci i młodzieży przez kilku badaczy. Janssen i wsp. [31] odkryli, że u dzieci i młodzieży bez skrzywienia kręgosłupa występuje wzorzec physiotherapist used the same device, i.e. Rippstein plurimeter, to assess the same person twice with short time intervals. To date, Rippstein plurimeter has been used in scientific research for angle measurements of the location and movements of the spine, shoulder and hip joint $[12,27,28,29,30]$. The greatest influence on the measurement value may have been exerted by body build of the examined girls and the quality of the protocol realisation.

Prior to the research, during the process of perfecting the TPHA test performance, the most problematic aspect was to acquire the ability to feel the final range of motion together with stabilising the subject's chest and to make the measurement with a plurimeter. Therefore, during the research the test was performed slowly with particular attention paid to stabilising the chest and the measurement made five seconds after finishing the movement. A higher level of control by the researcher was necessary in the case of individuals with higher body mass. Due to this fact, the reliability of the TPHA test in adults should be investigated.

It is hard to refer our findings to the results obtained by other researchers, since, to the best of our knowledge, no one had ever implemented and verified such a method of assessing the range of motion of the trunk-pelvis-hip complex.

In our research, significant differences between the ranges of motion of TPHA on the left and right side of the body were noted in both groups. In the majority of the girls the range of motion of TPHAleft was higher than that of TPHAright.

Different ranges of motion in the healthy girls may be related to the physiological asymmetry of vertebrae in the transverse plane which was noted in children and youth by some researchers. Janssen et al. [31] revealed that in healthy children and youth there occurred a rotational pattern of the vertebrae which may lead to scoliosis. The researchers noted that in the case of children under 3 years of age, T2-T6 vertebrae had a left-side rotation, while in the case of teenagers, T6T12 vertebrae had a right-side rotation. Additionally, in further research it was found that lumbar vertebrae in children under 3 years of age rotated to the left, but the rotation was not significant in older age [32]. It proves that the vertebrae rotation pattern changes with time. It may be confirmed by the research with the use of computer tomography carried out on adults whose T2-T4 vertebrae had a tendency to rotate to the left, while T5-L5 vertebrae rotated to the right [33].

It is noteworthy that in our research differences between the ranges of motion on the left and right side of the body occurred more often in scoliotic girls than in their healthy counterparts. Furthermore, a significant difference between healthy and scoliotic girls concerning TPHAright movement limitation was noted. It may suggest that the movement asymmetry in the transverse plane in healthy individuals as well as in- 
rotacyjny kręgów, który może prowadzić do powstania skoliozy. Badacze zaobserwowali, że u dzieci poniżej 3 roku życia kręgi T2 - T6 ustawione są w rotacji lewostronnej, podczas gdy u nastolatków kręgi T6-T12 ustawione są w rotacji prawostronnej. W późniejszych badaniach stwierdzono dodatkowo, że kręgi lędźwiowe u dzieci poniżej 3 roku życia zrotowane są w lewo, ale rotacja ta nie jest istotna w okresie późniejszym [32]. Wynika z tego, że wzorzec rotacyjny kręgów zmienia się w czasie rozwoju osobniczego. Potwierdzeniem tego mogą być badania z wykorzystaniem tomografii komputerowej przeprowadzone z udziałem dorosłych osób, u których zaobserwowano, że na poziomie T2-T4 kręgi mają tendencję do rotacji lewostronnej, a kręgi T5 - L5 kręgi wykazują rotację w prawo [33].

Warto zwrócić uwagę, że w prezentowanych badaniach u dziewcząt ze skoliozą różnice między zakresami ruchu po lewej i po prawej stronie występowały częściej niż w grupie dziewcząt bez skoliozy. Dodatkowo stwierdzono znamienne ograniczenie ruchu TPHAright względem zdrowych dziewcząt. Może to sugerować, że asymetria ruchów w płaszczyźnie poprzecznej u osób bez skoliozy i postępujące ograniczenia zakresów ruchu mogą być czynnikami predysponującymi do zapoczątkowania mechanizmów kompensacyjnych, a w efekcie do powstania skoliozy. Potwierdzałoby to pojawiające się wcześniej opinie, że brak symetrii ruchów w płaszczyźnie poprzecznej może sprzyjać rozwojowi skoliozy [31, 32, 33, 34].

W przeszłości także w innych badaniach wykazano związki między skrzywieniem kręgosłupa a zakresami ruchów kręgosłupa i miednicy w płaszczyźnie poprzecznej. Poussa i Mellin badając dziewczęta ze skoliozą idiopatyczną zauważyli, że wraz ze wzrostem skrzywienia zmniejszają się zakresy ruchów rotacyjnych [35]. We wcześniejszych badaniach Stępień [11] zaobserwowano, że u dziewcząt $\mathrm{z}$ dwułukową skoliozą idiopatyczną występuje asymetria ruchów rotacyjnych tułowia i miednicy. W badaniach stwierdzono między innymi ograniczenie zakresu lewostronnej rotacji tułowia względem miednicy oraz ograniczenie zakresu ruchu prawostronnej rotacji miednicy względem ustabilizowanego tułowia w odniesieniu do grupy dziewcząt bez skoliozy. W niniejszych badaniach, również w grupie dziewcząt ze skoliozą dwułukową, zaobserwowano istotne ograniczenie zakresu ruchu miednicy i kończyn dolnych po prawej stronie w porównaniu do grupy zdrowych dziewcząt. Test TPHA potwierdził więc wyniki wcześniejszych badań, mimo że metodyka obu badań była odmienna.

Test TPHA wymaga ustawienia kręgosłupa w zgięciu, zgięciu bocznym i rotacji oraz zgięcia, niewielkiego odwiedzenia/ przywiedzenia i rotacji w stawach biodrowych. Każda z tych składowych może wpływać na ostateczny pomiar zakresu ruchu w teście TPHA. Najważniejszą składową testu TPHA jest rotacja krę- creasing limitations in the ranges of motion might be the factors predisposing to compensatory mechanisms leading to scoliosis. This would confirm earlier opinions that the lack of the symmetry of movements in the transverse plane may facilitate the development of scoliosis [31, 32, 33, 34].

Also, earlier studies revealed the correlation between spinal curvatures and ranges of motion of the spine and pelvis in the transverse plane. While examining girls with idiopathic scoliosis, Poussa and Mellin noted that the bigger the curvature, the smaller the rotational ranges of motion [35]. In her earlier research, Stępień [11] noted that in girls with double idiopathic scoliosis there occurred an asymmetry of rotational movement of the trunk and pelvis. Additionally, compared to the healthy girls, the limitation in the range of motion of the left-side rotation of the trunk with regard to the pelvis and the right-side rotation of the pelvis with regard to the stabilised trunk was higher in scoliotic girls. In our research, a significant limitation of the range of motion of pelvis and upper limbs on the right side was also noted in the group of girls with double scoliosis. The TPHA test confirmed the results of the previous research, although the methodology of the two studies was different.

The TPHA test requires the spine to be bent, bent laterally or rotated and lower limbs to be extended/ flexed and rotated in hip joints. Each of these elements may affect the final measurement of the range of motion in TPHA test. The spine rotation is the most significant element of this test. Rotational movement occurs in numerous everyday life activities and thus, measurements of the range of motion in the transverse plane are significant both at the stage of planning physiotherapeutic procedures in individuals with musculoskeletal system dysfunctions and at the initial stage of prophylactic activities.

In the past, other researchers measured the range of motion of the trunk, pelvis and spine in the transverse plane. Iveson et al. [22] presented a simple method of measuring the trunk rotation while lying on one side, indicating excellent intra-observer reliability and good inter-observer reliability. They revealed that in the majority of patients with musculoskeletal system dysfunctions there occurs rotation asymmetry. Johnson et al. [23] suggested and verified five tests examining trunk rotation in three major positions: seated rotation, half-kneeling rotation and lumbar-locked rotation. They noted very high reliability of most tests. The ICC values obtained in our research are close to the results obtained by Iveson et al. [22] and Johnson et al. [23].

The TPHA test has numerous advantages. For instance, it is easy to use and takes little time. The test was created for children and youth with an improper body posture and scoliosis whose spine, pelvis and hip mobility was disturbed. 
gosłupa. Ruchy rotacyjne występują w wielu aktywnościach życia codziennego, stąd też pomiary zakresu ruchów w płaszczyźnie poprzecznej mają duże znaczenie zarówno na etapie planowania postępowania fizjoterapeutycznego u osób z rozpoznanymi dysfunkcjami narządu ruchu, jak i we wstępnej fazie działań profilaktycznych.

W przeszłości inni badacze podjęli próbę oceny pomiaru zakresu ruchu tułowia, miednicy, kręgosłupa w płaszczyźnie poprzecznej. Iveson et al. [22] przedstawili prostą metodę pomiaru rotacji tułowia w pozycji leżącej na boku, wykazując znakomity poziom rzetelności w przypadku wykonywania pomiarów przez jednego badacza i dobry poziom dla pomiarów prowadzonych przez kilku badaczy. Wykazali, że u większości pacjentów z dysfunkcjami narządu ruchu występuje asymetria ruchów rotacyjnych. Johnson et al. [23] zaproponowali i zweryfikowali pięć testów rotacji tułowia w trzech zasadniczych pozycjach: siedzącej, klęku jednonóż i pozycji na czworaka z podporem na przedramionach. Zaobserwowali bardzo wysoką rzetelność $\mathrm{w}$ większości $\mathrm{z}$ przedstawianych testów. Wartości ICC uzyskane w niniejszych badaniach są zbliżone do wyników uzyskanych przez Iveson et. al. [22] oraz Johnson et. Al. [23].

Test TPHA ma wiele zalet - jest prosty w wykonaniu i zajmuje niewiele czasu. Test powstał z myślą o dzieciach i młodzieży z nieprawidłową postawą ciała i skoliozą, u których dochodzi do zaburzeń funkcji ruchowej kręgosłupa, miednicy i stawów biodrowych.

W przeprowadzonych badaniach test TPHA wykazał asymetrię zakresu ruchów po lewej i prawej stronie ciała u większości badanych osób, potwierdzając istnienie fizjologicznej asymetrii ruchów u dzieci i młodzieży. W badaniach wykazano także istotne różnice w zakresach ruchu między dziewczętami ze skoliozą i bez skoliozy. Te wyniki pozwalają sądzić, że test TPHA może być też użyteczny w ocenie funkcjonalnej dzieci i młodzieży, zarówno zdrowych jak i z deformacjami narządu ruchu.

Nieprawidłowe ustawienie ciała $i$ asymetryczne wzorce ruchowe powstałe $\mathrm{w}$ okresie dzieciństwa mogą z czasem prowadzić do kompensacji i deformacji w narządzie ruchu oraz dolegliwości bólowych. W wielu wcześniejszych badaniach zaobserwowano, że u osób z dolegliwościami bólowymi odcinka lędźwiowego kręgosłupa (ang. low back pain - LBP) występują zaburzenia koordynacji, asymetria ruchów tułowia i miednicy, spowolnienie oraz ograniczenie zakresów ruchu w odcinku lędźwiowym kręgosłupa $[4,5,6,8,9$, 22]. Wykazano, że ograniczone zakresy ruchu kompleksu lędźwiowo- miednicznego w płaszczyźnie poprzecznej mogą być kompensowane w stawach biodrowych [7]. Al-Eisa et al. [5] udowodnili, że u osób z LBP występuje asymetria zakresu ruchów tułowia, która ma związek z nieprawidłowym ustawieniem miednicy [5]. Park et al. [8] badając zakresy rotacji tułowia i miednicy w pozycji stojącej odkryli, że u osób
In our research, the TPHA test revealed an asymmetry of the ranges of motion on the left and right side of the body in the majority of the examined individuals, which confirmed the existence of physiological asymmetry of movements in children and youth. The research also revealed significant differences between girls with and without scoliosis concerning the ranges of motion. These results allowed us to conclude that the TPHA test may also be useful in the functional assessment of children and youth, both healthy ones and those with musculoskeletal deformities.

An improper body position and asymmetric movement patterns which occurred in childhood may lead to compensation and deformity in the musculoskeletal system as well as to pain. In earlier research it was noted that individuals with low back pain (LBP) suffered from coordination disorders, trunk and pelvis movement asymmetry, as well as slower and limited ranges of motion in the lumbar spine $[4,5,6,8,9,22]$. It was revealed that limited ranges of motion of the lumbar-pelvic complex in the transverse plane may be compensated in hip joints [7]. Al-Eisa et al. [5] proved that in individuals with LBP there occurred an asymmetry of the trunk range of motion which is associated with an improper position of the pelvis [5]. When examining ranges of motion of the trunk and pelvis in a standing position, Park et al. [8] concluded that individuals with LBP had a limited rotational range of motion, with the biggest differences in pelvis movements. Moreover, the authors concluded that a limited range of motion is also dependent on gender and the limitation increases with age. Numerous studies indicated that pelvic and lumbar segment exert the biggest influence on body movements in a sitting position and during gait. It seems that the TPHA test may be used in the functional diagnostics of individuals with LBP; however, the reliability of this test would have to be confirmed in the group of adults.

Movements of pelvis and lower limbs [1], and especially rotational pelvic movements [2] affect spinal movements during gait. An improper pattern of movements in the transverse plane during gait may lead to scoliosis [36]. Therefore, the functional diagnostics of the trunk-pelvis-hip complex movements in individuals with a disturbed gait pattern seems more significant not only in the process of treatment but also at the stage of prophylactic activities preventing improper compensation mechanisms and secondary deformities.

The TPHA test has certain limitations. One of them is the fact that the measurements were made during one session with short, 3-minute intervals. On the other hand, it was easier to make the measurements on the same day and the influence of other factors which may have affected the subjects during long intervals between the tests was eliminated. In the future, the intra-observer reliability of the TPHA test performed with one-day and longer intervals as well as inter-observer reliability should be assessed. It is not clearly 
z LBP dochodzi do ograniczenia zakresu ruchów rotacyjnych, a największe różnice stwierdzono w ruchach miednicy. Autorzy stwierdzili także, że ograniczenia zakresu są zależne od płci i wzrastają z wiekiem. Wiele badań wykazuje więc, że to ruchy miednicy i odcinka lędźwiowego mają decydujący wpływ na mechanikę ciała w pozycji stojącej i podczas chodu. Wiele wskazuje na to, że test TPHA mógłby być wykorzystywany do diagnostyki funkcjonalnej osób z LBP, pod warunkiem potwierdzenia rzetelności tego testu $\mathrm{w}$ grupie dorosłych.

Ruchy miednicy i kończyn dolnych [1], a zwłaszcza ruchy rotacyjne miednicy [2] wpływają podczas chodu na ruchy kręgosłupa. Nieprawidłowy wzorzec ruchów w płaszczyźnie poprzecznej podczas chodu może sprzyjać powstaniu skoliozy [36]. Tym istotniejsza wydaje się więc diagnostyka funkcjonalna ruchów kompleksu tułów- miednica- biodro u osób w różnym wieku z zaburzonym wzorcem chodu, nie tylko w procesie leczenia, ale na etapie działań profilaktycznych przeciwdziałających nieprawidłowym mechanizmom kompensacyjnym i wtórnym deformacjom.

Test TPHA posiada pewne ograniczenia. Jednym z ograniczeń jest fakt, że pomiarów dokonano w czasie jednej sesji, w krótkich, 3 minutowych, odstępach czasowych. Z drugiej jednak strony wykonanie pomiarów tego samego dnia stanowiło duże ułatwienie organizacyjne i eliminowało wpływ innych czynników, które mogły działać na uczestników badania w długich przerwach między pomiarami. W przyszłości należy ocenić wiarygodność TPHA podczas dokonywania pomiarów w odstępach dobowych i dłuższych przez jednego badacza oraz rzetelność testu w przypadku prowadzenia pomiarów przez kilku badaczy. Nie wiadomo dokładnie jakie zakresy ruchu mierzy test, bowiem wykonywany ruch jest ruchem złożonym. Niewątpliwie najbardziej widoczny jest ruch w płaszczyźnie poprzecznej, ale nie należy pomijać ruchu kręgosłupa w płaszczyźnie strzałkowej i czołowej oraz ruchów w stawach biodrowych. Dlatego test TPHA wymaga dalszej oceny w połaczeniu z nowoczesnymi systemami analizy ruchu, które umożliwią poznanie jego poszczególnych składowych.

\section{Wnioski}

1. Test TPHA jest rzetelnym sposobem oceny ruchomości kompleksu kręgosłupowo- miedniczno- biodrowego u dziewcząt prowadzonej przez jednego badacza.

2. Asymetrię ruchów kompleksu kręgosłupowo miedniczno - biodrowego występującą u zdrowych dziewcząt należy poddać obserwacji, ponieważ może stanowić jeden z czynników predysponujących do rozwoju skoliozy.

3. Skolioza wpływa na ograniczenie zakresów ruchów rotacyjnych kręgosłupa.

4. Test TPHA wymaga dalszych badań. known which ranges of motion are measured with this test, since the performed movement is quite complex. Undoubtedly, the most visible movement is the one in the transverse plane; however, spine movement in the sagittal or coronal plane as well as movements in hip joints should not be neglected. Therefore, the TPHA test needs further assessment in correlation with modern systems of movement analysis which make it possible to assess its particular elements.

\section{Conclusions}

The TPHA test is a reliable means of assessing the mobility of trunk-pelvis-hip complex in girls by one researcher.

The asymmetry of movements in the lumbo-pelvic -hip complex in healthy girls needs to be observed since it may constitute one of the factors predisposing to scoliosis.

Scoliosis may limit the rotational ranges of motion of the spine.

The TPHA test needs further research. 


\section{Piśmiennictwo/References}

1. Crosbie J, Vachalathitib R, Smith R. Patterns of spinal motion during walking. Gait Posture 1997;5:6-2.

2. Yang YT, Yoshida Y, Hortobágyi T, Suzuki S. Interaction Between Thorax, Lumbar, and Pelvis Movements in the Transverse Plane During Gait at Three Velocities. J Appl Biochem 2013;29:261-269.

3. Schache AG, Bennell KL, Blanch PD, Wrigley TV. The coordinated movement of the lumbo-pelvic-hip complex during running: a literature review. Gait Posture 1999;10:30-47.

4. Selles RW, Wagenaar RC, Smit TH, Wuisman PI. Disorders in trunk rotation during walking in patients with low back pain: a dynamical systems approach. Clin Biomech 2001 March;16(3):175-1.

5. Al-Eisa E, Egan D, Deluzio K, Wassersug R. Effects of pelvic asymmetry and low back pain on trunk kinematics during sitting: a comparison with standing. Spine (Phila Pa 1976) 2006;31(5):135-3.

6. Laird RA, Gilbert J, Kent P, Keating JL. Comparing lumbo-pelvic kinematics in people with and without back pain: a systematic review and meta-analysis. BMC Musculoskeletal Disorders 2014;15:229.

7. Hoffman SL, Johnson MB, Zou D, Harris-Hayes M, Van Dillen LR. Effect of classification-specific treatment on lumbopelvic motion during hip rotation in people with low back pain. Man Ther 2011;16(4):344-0.

8. Park WH, Kim YH, Lee TR, Sung PS. Factors affecting shoulder-pelvic integration during axial trunk rotation in subjects with recurrent low back pain. Eur Spine J 2012;21(7):1316-3.

9. Sung PS. A kinematic analysis for shoulder and pelvis coordination during axial trunk rotation in subjects with and without recurrent low back pain. Gait Posture 2014;40(4):493-8.

10. Vaugoyeau M, Viallet F, Aurenty R, Assaiante C, Mesure S, Massion J. Axial rotation in Parkinson's disease. J Neurol Neurosurg Psychiatry 2006;77:815-1.

11. Stępień A. A range of rotation of the trunk and pelvis in girls with idiopathic scoliosis. Advances in Rehabilitation 2011;3:5-2.

12. Saur PM, Ensink FBM, Frese K, Seeger D, Hildebrandt J. Lumbar range of motion: reliability and validity of the inclinometer technique in the clinical measurement of trunk flexibility. Spine 1996;21(11):1332-8.

13. Malmström EM, Karlberg M, Melander A, Magnusson M. Zebris versus Myrin: a comparative study between a threedimensional ultrasound movement analysis and an inclinometer /compass method: intradevice reliability, concurrent validity, intertester comparison, intratester reliability, and intraindividual variability. Spine (Phila Pa 1976) 2003;28:433-0.

14. Cakir B, Richter M, Kafer W, Wieser M, Puhl W, Schmidt R. Evaluation of lumbar spine motion with dynamic x-ray-a reliability analysis. Spine 2006;31(11):1258-4.

15. Gauvin MG, Riddle DL, Rothstein JM. Reliability of clinical measurements of forward bending using the modified fingertipto-floor method. Phys Ther 1990;70:443-7.

16. Miller SA, Mayer T, Cox R, Gatchel RJ. Reliability problems associated with the modified Schober technique for true flexion measurement. Spine 1992;17:345-8.

17. Williams R, Binkley J, Bloch R, Goldsmith CH, Minuk T. Reliability of the modified-modified Schober and double inclinometer methods for measuring lumbar flexion and extension. Phys Ther 1993;73:33-4.

18. Tousignant M, Poulin L, Marchand S, Viau A, Place C. The Modified-Modified Schober Test for range of motion assessment of lumbar flexion in patients with low back pain: a study of criterion validity, intra- and inter-rater reliability and minimum metrically detectable change. Disabil Rehabil 2005 May 20;27(10):553-9.

19. Kolber MJ., Pizzini M, Robinson A, Yanez D, Hanney WJ. The reliability and concurrent validity of measurements used to quantify lumbar spine mobility: an analysis of an Iphone ${ }^{\mathbb{B}}$ application and gravity based inclinometry. Int J Sports Phys Ther 2013;8(2):129-7.

20. Robinson HS, Mengshoel AM. Assessments of lumbar flexion range of motion: intertester reliability and concurrent validity of 2 commonly used clinical tests. Spine (Phila Pa 1976) 2014; Feb15;39(4):E270-5.

21. MacDermid JC, Arumugam V, Vincent JI, Payne KL, So AK. Reliability of three landmarking methods for dual inclinometry measurements of lumbar flexion and extension. BMC Musculoskeletal Disord 2015;16:121.

22. Iveson BD, McLaughlin SL, Todd RH, Gerber JP. Reliability and exploration of the side- lying thoraco- lumbar rotation measurement (STRM). N Am J Sports Phys Ther 2010;5(4):201-7.

23. Johnson KD, Kim KM, Yu BK, Saliba SA, Grindstaff TL. Reliability of Thoracic Spine Rotation Range of Motion Measurements in Healthy Adults. J Athl Train 2012;47(1):52-0.

24. Cicchetti DV. Guidelines, criteria, and rules of thumb for evaluating normed and standardized assessment instruments in psychology. Psychol Assess 1994;6(4):284-0.

25. Negrini S, Aulisa AG, Aulisa L, Circo AB, de Mauroy JC, Durmala J et al. 2011 SOSORT guidelines: Orthopaedic and Rehabilitation treatment of idiopathic scoliosis during growth. Scoliosis 2012,7:3.

26. Bialocerkowski AE, Bragge P. Measurement error and reliability testing: Application to rehabilitation. IJPTR 2008;15(10),422-7.

27. Mayer TG, Tencer AF, Kristoferson S, Mooney V. Use of noninvasive techniques for quantification of spinal range-of-motion in normal subjects and chronic low-back dysfunction patients. Spine 1984; 9(6):588-5.

28. 28. Green S, Buchbinder R, Forbes A, Bellamy N. A standardized protocol for measurement of range of movement of the shoulder using the Plurimeter-V inclinometer and assessment of its intrarater and interrater reliability. Arthritis Care Res 1998; 11:43-2.

29. Kluszczyński M. Częstość występowania wad postawy i asymetrii grzbietu w populacji dzieci wiejskich. Fizjoter Pol 2007; 7:71-9.

30. Sharma SP, Bærheim A, Kvåle A. Passive range of motion in patients with adhesive shoulder capsulitis, an intertester reliability study over eight weeks. BMC Musculoskeletal Disord 2015; 16:37.

31. Janssen MMA, Kouwenhoven JWM, Schlösser T, Viergever MA, Lambertus W, Castelein RM, Vincken KL. Analysis of Preexistent Vertebral Rotation in the Normal Infantile, Juvenile, and Adolescent Spine. Spine 2011;36(7): 486-1. 
32. Schlösser TP, Vincken KL, Attrach H, Kuijf HJ, Viergever MA, Janssen MM, Castelein RM. Quantitative analysis of the closure pattern of the neurocentral junction as related to preexistent rotation in the normal immature spine. The Spine Journal: Official Journal of the North American Spine Society 2013;13(7):756-3.

33. Kouwenhoven JW, Vincken KL, Bartels LW, Castelein RM. Analysis of preexistent vertebral rotation in the normal spine. Spine (Phila Pa 1976) 2006;31(13):1467-2.

34. Wong Ch. Mechanism of right thoracic adolescent idiopathic scoliosis at risk for progression; a unifying pathway of development by normal growth and imbalance. Scoliosis 2015;10:2.

35. Poussa M, Mellin G. Spinal mobility and posture in adolescent idiopathic scoliosis at three stages of curve magnitude. Spine 1992;17:757-0.

36. Burwell RG, Cole AA, Cook TA, Grivas TB, Kiel AW, Moulton A, Thirwall AS, Upadhay SS, Webb JK, Wemyss-Holden SA, Whitwell DJ, Wojcik AS, Wythers DJ: Pathogenesis of idiopathic scoliosis. The Nottingham concept. Acta Orthop Belg. 1992,58:33-58. 